\title{
Influence of Agronomic biofortification on Maize
}

\author{
Augustine Rajendran ${ }^{1, a, *}$, Imayavaramban Veeramani ${ }^{1, b}$ \\ ${ }^{1}$ Department of Agronomy, Faculty of Agriculture, Annamalai University, Chidambaram - 608002. India
}

*Corresponding author

A R T I C L E I N F A B S T R A C T

Research Article

An experiment was carried out at the ICAR-KVK Research farm, HansRoever Campus, Perambalur, Tamil Nadu, India during the Kharif season (July to October), 2020 to study the effect of agronomic biofortification through integrated nutrient management on hybrid maize (biofortified and non-biofortified). The experiment was laid out in Split Plot Design having 36 treatment

Received : 10/09/2021

Accepted : 09/11/2021 combinations of hybrids and nutrients and replicated thrice. The treatment sources consisted of two main plots of maize hybrids ( $\mathrm{M}_{1}$ : Non-biofortified and $\mathrm{M}_{2}$ : biofortified), and six sub-plots of nutrients $\left(\mathrm{S}_{1}: 100 \%\right.$ Recommended Dose of Fertilizer RDF through Nitrogen, Phosphorus, Potassium, $\mathrm{S}_{2}: 100 \%$ RDF through Farm Yard Manure, $\mathrm{S}_{3}: 50 \%$ RDF through NPK $+50 \%$ RDF through FYM, $\mathrm{S}_{4}: \mathrm{S}_{1}+$ Iron and Zinc as foliar application @ $0.5 \%$ conc, $\mathrm{S}_{5}: \mathrm{S}_{2}+$ Iron and Zinc as foliar application @0.5\% conc, $\mathrm{S}_{6}: \mathrm{S}_{3}+$ Iron and Zinc as foliar application @0.5\% conc.). The recommended dose of fertilizer was NPK 150:75:75 $\mathrm{kg} \mathrm{ha}^{-1}$. Application of 50\% RDF through NPK $+50 \%$ RDF through FYM with Fe and $\mathrm{Zn}$ as foliar application @ $0.5 \%$ conc $\left(\mathrm{S}_{6}\right)$ at 45 (active vegetative stage) and 90 (grain filling stage) days after sowing, significantly increased all the growth and yield attributes, grain and stover yield, quality attributes and nutrient uptake by maize. Among the nutrient levels, higher grain yield $\left(8.2 \mathrm{t} \mathrm{ha}^{-1}\right)$ and stover yield $\left(10.16 \mathrm{t} \mathrm{ha}^{-1}\right)$, quality attributes, and nutrient uptake were recorded with the application of $50 \%$ RDF through NPK $+50 \%$ RDF through FYM with Fe and $\mathrm{Zn}$ as foliar application @ $0.5 \%$ conc $\left(\mathrm{S}_{6}\right)$. Similarly, significant net return (INR 78,767) and benefit cost ratio (3.07) were noted with the application of $100 \%$ RDF through NPK $\left(\mathrm{S}_{1}\right)$ followed by $50 \%$ RDF through NPK + 50\% RDF through FYM with Fe and Zn as foliar application @ $0.5 \%$ conc $\left(\mathrm{S}_{6}\right)$. Hence, integrated nutrient management with agronomic biofortification @ $0.5 \%$ conc., at $45^{\text {th }}$ and $90^{\text {th }}$ DAS should be adopted to obtain maximum grain yield, net profit, and nutrient uptake by Kharif maize.

\section{Introduction}

An estimated two billion people are affected by an unbalanced proportion of micronutrients called "micronutrient malnutrition" or "hidden hunger" (Steur et al., 2015). The problem of micronutrient deficiencies is widespread in developing and under-developed countries, where they mainly depend on cereal-based diets as a staple food (Korkmaz et al., 2021). India estimated that 15.2 percent of people are undernourished (Global food policy report, 2016).

There was a need to deliver nutritious, safe, and affordable food to the population, reducing nutritional insecurity. Interventions like an industrial-food fortification, supplementation, and dietary diversification have tried to mitigate micronutrient deficiencies worldwide. None of these were found viable due to ineffective distribution and non-affordability (Tanumihardjo et al., 2007). On the other hand, the development of mineral-enriched staple foods through breeding and agronomic approaches gained significance through the process known as "biofortification," which holds promise for cost-effective and sustainable dietary solutions combat micronutrient deficiencies (Pfeiffer and McClafferty, 2007).

Maize is an important cereal crop of India for a larger section of populations, raw material for industries, and feed for animals and plays a major role in the agro-based economy (Ibrikci et al., 2009). Unfortunately, normal maize has significant flaws in nutritional quality; it lacks a full range of amino acids, namely lysine and tryptophan causing major threats to nutritional security. Biofortified maize produces $70-100 \%$ more essential amino acids (lysine and tryptophan) than the most modern varieties of tropical maize (Augustine and Kalyanasundaram, 2020). 
In this context growing biofortified maize hybrid with high lysine and tryptophan will play a pivotal role in eliminating protein-calorie malnutrition (Jat et al., 2013). Genotypes with denser grains are developed and need to be adequately fertilized with iron and zinc. Nutrient management plays a key role in sustaining the productivity of this system, as maize crop requires higher level fertilization.

Agronomic biofortification is one such unique practice done through fertilization with nutrients and has been extensively used in maize with supplemental foliar spray to increase the grain's high concentrations of nutrients. Even though this practice is common in crops, spraying minerals at the appropriate time during plant growth turns to an efficient nutritional starter/gainer in plant parts which helps in direct nutritional support to the human population and animals, etc. (Monika Garg et al., 2018). In this scenario, Agronomic biofortification - using INM is advocated as a viable approach for maintaining and sustaining proper plant growth and productivity and providing crop stability during production (Muhammad Sarwar et al., 2012). Biofortification recovery, the term suggests that foliar application was about eight times higher than obtained from soil application (Impa and Johnson-Beebout, 2012). The foliar application implies that nutrients applied will be absorbed by the leaf (point of application) to the growing tissues (point of utilization), and the export of nutrients from leaves transport downwards exclusively to the phloem (Rengel et al., 1999). Furthermore, Guleria et al. (2013) highlighted the potential of kernel $\mathrm{Fe}$ and $\mathrm{Zn}$ concentrations in grain, which are significantly influenced by soil type, soil fertility, soil moisture, and interactions among nutrients. The characteristics and importance of this Agronomic biofortification ( $\mathrm{Fe}$ and $\mathrm{Zn}$ foliar application) for the maize-production chain justifies the need to evaluate performance in association with INM and biofortified hybrids.

\section{Materials and Methods}

A field experiment was conducted at ICAR-KVK farm, Hans Roever campus, Perambalur district, Tamil Nadu state, India during the period from July 2020 to October 2020 (Kharif season) to study the productivity, profitability, and uptake of maize hybrids. The experiment was laid out in split-plot design (SPD) with twelve treatment combinations of two hybrids $(\mathrm{H}) \mathrm{NK} 6668\left(\mathrm{M}_{1}\right)$ as non-biofortified maize hybrid from Syngenta and $\mathrm{VH}$ $133545\left(\mathrm{M}_{2}\right)$ as biofortified maize hybrid obtained from CIMMYT, Hyderabad in main plots and six nutrient (N) levels in sub-plots with three replications. Hybrids of nonbiofortified ( $\left.\mathrm{M}_{1}-\mathrm{NK} 6668\right)$ a prolific yielder and biofortified ( $\mathrm{M}_{2}$-CIMMYT hybrid) were tested. The six nutrient levels taken in the experiment were $\mathrm{S}_{1}: 100 \% \mathrm{RDF}$ through NPK, $\mathrm{S}_{2}: 100 \%$ RDF through FYM, $\mathrm{S}_{3}: 50 \% \mathrm{RDF}$ through NPK + 50\% RDF through FYM, $\mathrm{S}_{4}: \mathrm{S}_{1}+$ Iron and Zinc as foliar application @ $0.5 \%$ conc, $\mathrm{S}_{5}: \mathrm{S}_{2}+$ Iron and Zinc as foliar application @ $0.5 \%$ conc, $S_{6}: S_{3}+$ Iron and Zinc as foliar application @ $0.5 \%$ conc.

Hybrids and nutrient levels were randomized in main plots and sub-plots, respectively. The size of the unit plot was $5 \mathrm{~m} \times 4 \mathrm{~m}$. The total number of plots was 36 .
Land preparation started in the first week-July and fertilizers were applied as per treatment specification. In hybrid maize, the recommended was $333 \mathrm{~kg} \mathrm{ha}^{-1}$ urea + $468.75 \mathrm{~kg} \mathrm{ha}^{-1}$ single super phosphate $+125.25 \mathrm{~kg} \mathrm{ha}^{-1}$ muriate of potash. The rate of FYM was $10 \mathrm{t} \mathrm{ha}^{-1}$. Foliar application of $0.5 \% \mathrm{FeSo}_{4}$ and $\mathrm{ZnSo}_{4}$ as per treatments was done twice at active vegetative (45 days) and grain filling stage (90 days), respectively with the help of a knapsack sprayer. Seeding was done on 8 July 2020 at a spacing of $60 \mathrm{~cm} \times 20 \mathrm{~cm}$. The grain cobs were harvested on 7 November $2020\left(\mathrm{M}_{1}\right)$ and 28 October $2020 \quad\left(\mathrm{M}_{2}\right)$. Observations were made in the respect of plant height, leaf area index (LAI), dry matter production (DMP), days to $50 \%$ tasseling, days to $50 \%$ silking, cob length, cob girth, no. of grains per row, no. of rows per cob, cob weight, shelling\%, 1000-grain weight, grain yield ha-1 ${ }^{-1}$ stover yield $\mathrm{ha}^{-1}$, the net return, benefit-cost ratio (BCR), crude protein $\%$, starch, iron $(\mathrm{Fe})$, zinc $(\mathrm{Zn})$, nutrient uptake and soil available nutrients.

\section{Design of the Experiment and Layout}

The experiment was laid out in a split-plot design with three replications. The whole experimental area was first divided into three blocks. Each block was later divided into 12 plots. The size of each unit plot was $5 \mathrm{~m}$ x $4 \mathrm{~m}$. The total numbers of unit plots are 36. The individual plots and the blocks were separated for irrigation drainage by $1.0 \mathrm{~m}$ channels.

\section{Detailed procedures of Recording of Data}

\section{Growth parameters}

Plant height was measured with a graduated ruler, from the base of the plant to the growing tip of the topmost leaf of ten randomly taken from the net plot area. LAI was computed from the selected ten plants by measuring the leaf length and breadth of the third fully opened leaf from the top by $\mathrm{LAI}=1 \times \mathrm{b} \times \mathrm{n} \times 0.796 /$ plant spacing. Ten plants at random were cut close to the ground level from the sampling row for DMP estimation. Samples were sundried for three days followed by oven drying at $70^{\circ} \mathrm{C}$ for $72 \mathrm{hrs}$ till a constant weight was obtained and the dry weight was recorded.

\section{Crop Phenology}

Days to $50 \%$ tasseling (the number of days from planting to the start of shredding of pollen by $50 \%$ of maize plants in the plots) and days to $50 \%$ silking (number of days from planting to silking by $50 \%$ ) were recorded at their respective stages.

\section{Yield and Yield components}

Cob length was measured from the base to the tip of the cob from the sample plants of each treatment and the mean length of the cob was arrived at and expressed in $\mathrm{cm}$. The girth of cob from sample plants was measured at the point of maximum girth using a thread and measured with a scale. The mean girth per cob was computed and expressed in $\mathrm{cm}$. The number of grains in each row of a cob of the sample plants was counted. The mean was worked out and expressed as a number of grains per row. From the cobs collected from sample plants, the number of grain rows per cob was counted and the mean was arrived at and expressed as the number of rows per cob. The cobs of sample plants were dried thoroughly under the sun and their average weight was recorded and expressed in gm as cob weight. The shelling percentage can be determined from ten plants randomly sampled after harvest using the following formula (Undie et al., 2012): 
Shelling percentage $=($ Seed weight $/$ cob weight $) \times 100 \%$.

Ten cobs from each treatment were randomly selected and shelled. From this, a representative sample of 1000 maize grains was picked out and weighed using an electronic balance and expressed in g per 1000 grains and reported as 1000 grain weight. The shelled grains from the net plots were dried, cleaned, and again sun-dried and is calculated using the ear fresh weight and the adjusted moisture content (MC) percentage (from 10 to 15\%), by using the following formula (ASTM standards 2001):

$\mathrm{GY}=\mathrm{FEW} \times 10 \times(100-\mathrm{MC}) \times 0.8) /((100-\mathrm{AMC}) \times \mathrm{PA}$

Where

GY: Grain yield (t/ha)

FEW: Fresh ear weight (kg/plot)

AMC: adjusted MC

PA: Plot Area

In this case, fresh ear weight is in $\mathrm{kg}$, moisture content (MC) of grains and adjusted MC in percentage (\%), 0.8 is the shelling coefficient, and the harvested plot area is in $\mathrm{m}^{2}$. After cob harvest, the Stover was cut close to ground level and left in the field for three days for sun drying. The dry weight of the stover was recorded plot-wise.

Quality attributes

The Fe and $\mathrm{Zn}$ determination by grain is done by using atomic absorption spectrophotometer (AAS; model 210 VGP, Buck scientific).

\section{Nutrient uptake}

$\mathrm{N}, \mathrm{P}$, and $\mathrm{K}$ were calculated by multiplying the content of the nutrients (expressed in percentage) with the respective weights of dry matter of the plant samples at the appropriate stage.

Economic return

Net return and BCR were calculated using the price of inputs and produce that prevailed during the crop season. Net returns $=($ Gross return - Cost of Cultivation $)$ and BCR $=($ Gross income $/$ Cost of Cultivation $)$.

\section{Statistical Analysis}

The collected data were compiled and tabulated before statistical analysis. Analysis of variance (ANOVA) was done with the help of a computer package (AGRES, 2020). The data recorded during the experiment were subjected to statistical analysis using the F-test as per the procedure given by Gomez and Gomez (1984). Critical difference values at $\mathrm{P}=0.05$ were used to determine the significance of differences between treatment means.

\section{Results and Discussions}

\section{Growth attributes}

\section{Plant Height}

The plant height of nutrient levels significantly varied due to different treatments. The plant height due to different treatments ranged from 219.33 to $184.50 \mathrm{~cm}$. The maximum plant height $(219.33 \mathrm{~cm})$ was obtained when $S_{6}$ treatment was applied. It was also found that the lowest plant height $(184.50 \mathrm{~cm})$ was noted with treatment $S_{1}$ (Table 1). The result might be due to the combined source of fertilizers, initially to get decomposed and mineralize before making it available to plants, thus causes nutrients to be slowly released to crop (Okoroafor et al., 2013). On the other hand, the lowest plant height observed in the $S_{3}$ is due to a lack of sufficient available nutrients to the crop.

\section{Leaf area index}

Leaf area index (LAI) of different nutrient level treatments varied from 3.35 to 4.63 . . The highest value (4.63) was experienced in the nutrient level treatment $S_{6}$ which was statistically significant with $S_{3}$ and $S_{1}$ with the value of 4.45 and 4.25 respectively. The lowest leaf area index (3.35) was obtained in treatment $S_{2}$ which was statistically on par with $S_{5}$ with the value of 3.65 (Table 1). In the present study, better utilization of $\mathrm{N}$ resulted in higher leaf surface area and thereby higher LAI. This is in accordance with earlier findings of Agyenium et al. (2006).

Dry matter production

The higher DMP at harvest of different nutrient level treatments varied from 13544.83 to $12475 \mathrm{~kg} \mathrm{ha}^{-1}$ and the maximum and minimum were found in the treatment $S_{6}$ and $S_{2}$ respectively. The $S_{6}$ was statistically similar to $S_{3}$ and $S_{1}$ with the value of 13400 and $13217 \mathrm{~kg} \mathrm{ha}^{-1}$ respectively. Application of $S_{1}$ treatment recorded the lowest DMP (12475 $\left.\mathrm{kg} \mathrm{ha}^{-1}\right)$ which was statistically similar with $\mathrm{S}_{5}$ treatment with the value of $12862.50 \mathrm{~kg} \mathrm{ha}^{-1}$ (Table 1). INM with micronutrient foliar spray enabled the leaf area duration to extend and provided an opportunity for the plants to increase the photosynthetic rate leading to the higher accumulation of dry matter. Similar results were recorded by Amanullah (1997). Leaf area index and dry matter were significantly correlated demonstrating that a higher amount of radiation associated with higher LAI contributes to enhanced dry matter production, which corroborated the results of Kolawole and Samson, (2009).

\section{Crop Phenology}

Tasseling and Silking

Days to $50 \%$ tasseling and silking of different nutrient level treatments varied from 57.65 to 54.05 and 66.20 to 60.35 respectively. In treatment, $\mathrm{S}_{6}$ recorded the reduced (faster) days to $50 \%$ tasseling and silking which was statistically similar to $\mathrm{S}_{4}$ with the value of 54.58. Application of $S_{2}$ treatment recorded the higher no. of days to $50 \%$ flowering with the value of 57.65 and 66.20 respectively (Table 1). A combined organic and inorganic source with micronutrient applications stimulates vegetative growth and ensuring higher yield. A similar result was found by Ayoola and Makinde, (2009).

\section{Yield and Yield attributes}

\section{Cob length}

The length of cob was significantly varied by the use of integrated nutrient management with $\mathrm{Fe}$ and $\mathrm{Zn}$ foliar applications. It was showed that cob length ranged from 18.18 to $15.70 \mathrm{~cm}$. The highest cob length $(18.18 \mathrm{~cm})$ was found in the $S_{6}$ treatment. The lowest result $(15.70 \mathrm{~cm})$ was recorded in $S_{2}$ nutrient level treatment which was statistically significant with $S_{5}$ treatment with the value of $16.15 \mathrm{~cm}$ (Table 1). Our results suggested that an adequate supply of nutrients from both organic and inorganic sources throughout vegetative growth was necessary for proper cob development in maize, as also reported by Samsami (2016). In the case of $\mathrm{S}_{2}$, the cob may be devoid of recommended demand of nutrients resulted in the lowest cob length. Similar results were recorded by Bukesh et al. (2012). 
Table 1. Growth and Yield attributes of hybrid maize (Zea mays L.) as influenced by Agronomic biofortification through INM

\begin{tabular}{|c|c|c|c|c|c|c|c|c|c|c|}
\hline \multirow{2}{*}{ Treatments } & \multicolumn{3}{|c|}{ Growth attributes } & \multicolumn{2}{|c|}{$\begin{array}{c}\text { Crop } \\
\text { phenology }\end{array}$} & \multicolumn{5}{|c|}{ Yield attributes } \\
\hline & $\mathrm{PH}$ & $\begin{array}{c}\text { LAI } \\
\text { At harv }\end{array}$ & $\begin{array}{l}{ }_{\text {est }} \text { DMP } \\
\end{array}$ & DT & DS & CL & $\mathrm{CG}$ & NGR & NRC & $\mathrm{C}$ \\
\hline \multicolumn{11}{|c|}{ Hybrid $(\mathrm{H})$} \\
\hline $\mathrm{M}_{1}-$ Non-biofortified & 207.83 & 4.19 & 13221.67 & 54.93 & 62.68 & 17.48 & 14.43 & 32.70 & 14.21 & 299.17 \\
\hline $\mathrm{M}_{2}-$ biofortified & 203.94 & 3.93 & 12960.78 & 56.42 & 62.76 & 16.43 & 14.13 & 32.62 & 14.03 & 269.22 \\
\hline \multicolumn{11}{|c|}{ Nutrient levels (N) } \\
\hline $\mathrm{S}_{1}$ & 211.00 & 4.25 & 13217.50 & 55.30 & 61.90 & 17.20 & 14.50 & 33.50 & 14.20 & 286.00 \\
\hline $\mathrm{S}_{2}$ & 184.50 & 3.35 & 12475.00 & 57.65 & 66.20 & 15.70 & 13.30 & 30.02 & 13.45 & 277.00 \\
\hline $\mathrm{S}_{3}$ & 214.50 & 4.45 & 13400.00 & 55.80 & 62.50 & 16.70 & 14.15 & 32.00 & 13.95 & 284.00 \\
\hline $\mathrm{S}_{4}$ & 208.50 & 4.05 & 13047.50 & 54.58 & 61.22 & 17.80 & 14.80 & 34.25 & 14.50 & 287.50 \\
\hline $\mathrm{S}_{5}$ & 197.50 & 3.65 & 12862.50 & 56.65 & 64.15 & 16.15 & 13.70 & 31.25 & 13.60 & 280.50 \\
\hline$S_{6}$ & 219.33 & 4.63 & 13544.83 & 54.05 & 60.35 & 18.18 & 15.25 & 35.55 & 15.02 & 290.17 \\
\hline F test Prob. & \multicolumn{10}{|c|}{$\mathrm{P}>\mathrm{F}$} \\
\hline $\mathrm{H}$ & $* *$ & N.S & $* *$ & $* *$ & N.S & $* *$ & N.S & N.S & N.S & $* *$ \\
\hline $\mathrm{N}$ & $* *$ & $* *$ & $* *$ & $* *$ & $* *$ & $* *$ & $* *$ & $* *$ & $* *$ & $* *$ \\
\hline $\mathrm{H} \times \mathrm{N}$ & $* *$ & $* *$ & $* *$ & $* *$ & $* *$ & $* *$ & $* *$ & $* *$ & $* *$ & $* *$ \\
\hline
\end{tabular}

PH: plant height (cm); LAI: leaf area index; DMP: dry matter production (Kg ha-1); DT: Days to 50\% tasselling, DS: Days to 50\% silking, CL: Cob length (cm), CG: Cob girth (cm), NGR: No. of grains row-1, NRC: No. of rows cob-1, C: Cob wt. (g), N: nitrogen, P: phosphorus, K: potassium; FYM: farm yard manure; RDF: recommended dose of fertilizer; **significantly different at 0.05 probability levels; N.S: not significant

$\mathrm{S}_{1}: \mathrm{S}_{1}-100 \%$ RDF through NPK, $\mathrm{S}_{2}: \mathrm{S}_{2}-100 \%$ RDF through FYM, $\mathrm{S}_{3}: \mathrm{S}_{3}-50 \%$ RDF through NPK $+50 \%$ RDF through FYM, $\mathrm{S}_{4}: \mathrm{S}_{4}-\mathrm{S}_{1}+$ Iron and Zinc as foliar application @ $0.5 \%$ conc, $\mathrm{S}_{5}: \mathrm{S}_{5}-\mathrm{S}_{2}+$ Iron and Zinc as foliar application @ $0.5 \%$ conc, $\mathrm{S}_{6}: \mathrm{S}_{6}-\mathrm{S}_{3}+$ Iron and Zinc as foliar application @ $0.5 \%$ conc

\section{Cob girth}

The effect of nutrient levels and hybrids on cob diameter was significant. The cob girth varied from 15.25 to $13.30 \mathrm{~cm}$ due to different nutrient level treatments. The highest cob girth $(15.25 \mathrm{~cm})$ was in the $S_{6}$ treatment. The least value $(13.30 \mathrm{~cm})$ of cob girth was in $S_{2}$ nutrient level treatment that was statistically similar to $S_{5}$ treatment with the value of $13.70 \mathrm{~cm}$ (Table 1).

The cob can make vigorous growth which causes an increase in diameter and similar findings were reported by Maidul et al. (2018), that sufficient nutrient supply may enhance the individual size of grain finally, which increases the cob diameter.

No. of Grains per Row

A significant variation in the number of grains per row was reflected due to the combined application of INM with $\mathrm{Fe}$ and $\mathrm{Zn}$ foliar applications. The number of grains per row varied with nutrient level treatments. The maximum (35.55) and the minimum (30.02) number of grains per row were found with the treatment $S_{6}$ and $S_{2}$, respectively (Table 1). The increment in the number of grains per row might be due to the presence of micronutrient fertilizers. It was mainly due to the increase in nitrogen content in the soil which was responsible for the all-around enhancement of cell division within the plant. These results were in concurrence with the findings of Ahmad et al. (2017) in harmony with Ali et al. (2012).

\section{No. of Rows per Cob}

A significant variation in the number of rows per cob was noted due to different nutrient levels. The number of rows $\mathrm{cob}^{-1}$ due to different nutrient level treatments ranged from 15.02 to 13.45 . The highest value (15.02) of the number of rows $\mathrm{cob}^{-1}$ manifested with the treatment $\mathrm{S}_{6}$ which was statistically significant than all other nutrient levels. $S_{2}$ nutrient level treatment recorded the lowest value 13.45 in the number of rows $\mathrm{cob}^{-1}$. This treatment was statistically similar to $S_{5}$ and $S_{3}$ treatment with the value of
13.60 and 13.95 respectively (Table 1). Different micronutrients and their combination proved beneficial and salubrious in enhancing all physiological and yield parameters of maize crop and yield a good response in terms of the number of grains number of rows per cob. The result of the analysis was in line with the report shown by Kruczek (2005) and Uwah et al. (2011).

Cob weight

The effect of nutrient levels and hybrids on cob weight was significant. The cob weight varied from 290.17 to 277 $\mathrm{g}$ due to different nutrient level treatments. The highest cob weight $(290.17 \mathrm{~g})$ was in $\mathrm{S}_{6}$ nutrient level treatment. The least value $(277 \mathrm{~g})$ of cob weight was recorded in the treatment $S_{2}$ that was statistically not similar with any treatments (Table 1). The cob may store the highest amount of food from green parts of plants which causes the increased weight of the cob. Similar results were found by Maidul et al. (2018).

\section{Shelling\%}

A significant variation of shelling \% was reflected due to the combined application of agronomic fortification through INM. The shelling \% varied from different nutrient level treatments. The maximum (81.31) and the minimum (75.99) shelling\% were found in the treatment $\mathrm{S}_{6}$ and $\mathrm{S}_{2}$, respectively (Table 2). The shelling percentage is influenced by many factors such as agro-climatic conditions, years, locations, genotypes, cultural practices, and kernel moisture content and positively correlated with grain yield and has a significant association with plant height, ear height, number of kernels per row, and hundredgrain weight. Similar findings were reported by Masuka et al. (2017); Saleh et al. (2002).

\section{0-Grain Weight}

The result proves the attention to the effect of agronomic fortification through INM on the 1000-grain weight of hybrid maize. The variation was found to be slim due to different treatments. The highest value (236 g) was 
noted in treatment $\mathrm{S}_{6}$ (Table 2). The lowest value (211 g) was in treatment $S_{2}$. The similar increase of yield attributing characters was the main cause for increased maize yield in the combined application of $\mathrm{Fe}$ and $\mathrm{Zn}$ through foliage (Nikhil and Salakinkop, 2018).

Grain Yield per Hectare

There is a significant difference in grain yield was noted due to agronomic fortification through INM. The highest grain yield per hectare due to different treatments ranged from 8.27 to $7.90 \mathrm{tha}^{-1}$. The highest value $(8.27 \mathrm{t}$ $\mathrm{ha}^{-1}$ ) of grain yield per hectare manifested with the nutrient level treatment $S_{6} . S_{2}$ treatment produced the lowest value $\left(7.90 \mathrm{t} \mathrm{ha}^{-1}\right)$ of grain yield per ha (Table 2). The increase shows the synergetic role of micronutrient spray in improving plant growth and other biochemical and physiological activities. Similar results were confirmed by Zeidan (2010); Hythum and Nasser (2012).

\section{Stover Yield per Hectare}

The effect of agronomic biofortification treatment through INM on stover yield per hectare was statistically significant. The stover yield per hectare varied from 10.16 to $9.71 \mathrm{t} \mathrm{ha}^{-1}$. Stover yield per hectare was highest $(10.16 \mathrm{t}$ $\mathrm{ha}^{-1}$ ) with $\mathrm{S}_{6}$ nutrient level treatments. The least value (9.71 $\mathrm{t} \mathrm{ha}^{-1}$ ) of stover yield per hectare was recorded in the treatment $S_{2}$ that was statistically similar with $S_{5}$ with the value of $9.99 \mathrm{t} \mathrm{ha}^{-1}$ (Table 2). Fertilization of $\mathrm{Zn}$ and the addition of organic manures significantly produced high grain and stover yield and thousand-grain weight (Sadiq et al. 2018).

Table 2. Yield, quality and economics of hybrid maize (Zea mays L.) as influenced by Agronomic biofortification through INM

\begin{tabular}{|c|c|c|c|c|c|c|c|c|c|c|}
\hline \multirow{2}{*}{ Treatments } & \multirow{2}{*}{ S } & \multirow{2}{*}{ GW } & \multicolumn{2}{|c|}{ Yield $\left(\mathrm{t} \mathrm{ha}^{-1}\right)$} & \multicolumn{2}{|c|}{ Economics } & \multicolumn{4}{|c|}{ Quality attributes } \\
\hline & & & GY & SY & NR & BCR & $\mathrm{CP}$ & ST & $\mathrm{Fe}$ & $\mathrm{Zn}$ \\
\hline \multicolumn{11}{|c|}{ Hybrid $(\mathrm{H})$} \\
\hline$M_{1}-$ Non-biofortified & 80.54 & 241.0 & 8.53 & 10.20 & 79619.17 & 3.00 & 10.48 & 59.77 & 28.57 & 24.23 \\
\hline $\mathrm{M}_{2}-$ biofortified & 75.69 & 203.8 & 7.68 & 9.87 & 69501.03 & 2.75 & 14.63 & 62.12 & 30.43 & 24.88 \\
\hline \multicolumn{11}{|c|}{ Nutrient levels $(\mathrm{N})$} \\
\hline $\mathrm{S}_{1}$ & 78.02 & 223.5 & 8.15 & 10.13 & 78767.07 & 3.07 & 11.10 & 59.45 & 22.75 & 18.50 \\
\hline $\mathrm{S}_{2}$ & 75.99 & 211.0 & 7.90 & 9.71 & 72709.00 & 2.77 & 10.60 & 58.40 & 21.20 & 16.95 \\
\hline $\mathrm{S}_{3}$ & 77.69 & 221.0 & 8.20 & 10.15 & 75199.50 & 2.90 & 11.50 & 60.50 & 23.70 & 19.50 \\
\hline $\mathrm{S}_{4}$ & 79.19 & 228.0 & 8.10 & 10.08 & 74549.33 & 2.93 & 14.00 & 62.10 & 36.35 & 30.75 \\
\hline $\mathrm{S}_{5}$ & 76.49 & 215.0 & 8.00 & 9.99 & 70421.70 & 2.69 & 13.50 & 61.37 & 35.20 & 29.75 \\
\hline $\mathrm{S}_{6}$ & 81.31 & 236.0 & 8.27 & 10.16 & 75714.00 & 2.89 & 14.65 & 63.85 & 37.80 & 31.88 \\
\hline F test Prob. & \multicolumn{10}{|c|}{$\mathrm{P}>\mathrm{F}$} \\
\hline $\mathrm{H}$ & $* *$ & $* *$ & $* *$ & $* *$ & NS & $* *$ & $* *$ & NS & $* *$ & $* *$ \\
\hline $\mathrm{N}$ & $* *$ & $* *$ & $* *$ & $* *$ & $* *$ & $* *$ & $* *$ & $* *$ & $* *$ & $* *$ \\
\hline $\mathrm{H} \times \mathrm{N}$ & $* *$ & $* *$ & $* *$ & $* *$ & $* *$ & $* *$ & $* *$ & $* *$ & $* *$ & $* *$ \\
\hline
\end{tabular}

S: Shelling \%, GW: 1000-Grain weight (g), GY: Grain yield, SY: Stover yield, NR: Net return $\left(\times 10^{3}\right.$ INR/ha ), BCR: Benefit Cost ratio, CP: Crude Protein (\%), ST: Starch (mg g$\left.{ }^{-1}\right)$, Fe: iron(mg kg-1), Zn: zinc (mg kg-1), NPK: nitrogen, phosphorus, potassium, FYM: farm yard manure, RDF: recommended dose of fertilizer, $* *$ significantly different at 0.05 probability levels, N.S: not significant

$\mathrm{S}_{1}: \mathrm{S}_{1}-100 \%$ RDF through NPK, $\mathrm{S}_{2}: \mathrm{S}_{2}-100 \%$ RDF through FYM, $\mathrm{S}_{3}: \mathrm{S}_{3}-50 \%$ RDF through NPK + 50\% RDF through FYM, $\mathrm{S}_{4}: \mathrm{S}_{4}-\mathrm{S}_{1}+$ Iron and Zinc as foliar application @ $0.5 \%$ conc, $\mathrm{S}_{5}$ : $\mathrm{S}_{5}-\mathrm{S}_{2}+$ Iron and Zinc as foliar application @ 0.5\% conc, $\mathrm{S}_{6}$ : $\mathrm{S}_{6}-\mathrm{S}_{3}+$ Iron and Zinc as foliar application $@ 0.5 \%$ conc

\section{Economic Returns}

\section{Net Return}

The effect of treatment with agronomic biofortification through INM on net return was statistically significant. The highest net return (INR 78767.07 ha-1) was recorded in the $\mathrm{S}_{1}$ nutrient level treatment followed by $\mathrm{S}_{6}$ (INR 75714 ha $\left.{ }^{1}\right)$. This was statistically similar to $S_{3}\left(\right.$ INR 75199.50 ha $\left.^{-1}\right)$ treatment. On the other hand, the lowest net return (INR $70421.70 \mathrm{ha}^{-1}$ ) was recorded in the $\mathrm{S}_{5}$ nutrient level treatment (Table 2). The result might be because of the minimum cost of cultivation and favorable minimum support price during the Kharif season. This confirms the findings of Kumar et al. (2007).

\section{Benefit-Cost Ratio}

A significant variation of BCR was noted due to different nutrient level treatments. The BCR varied from 3.07 to 2.77 due to different treatments. The highest BCR (3.07) was in the $S_{1}$ nutrient level treatment. The least value (2.77) of BCR was recorded in the $S_{2}$ treatment (Table 2). This confirms the findings of Kumar et al. (2007) and Kumari et al. (2010).

\section{Quality attributes \\ Crude Protein}

The effect of agronomic biofortification through INM on the crude protein was statistically significant. The crude protein varied from 14.65 to $10.60 \%$. Crude protein was highest $(14.65 \%)$ with $\mathrm{S}_{6}$ treatment. The least value (10.60 $\%$ ) of crude protein was recorded in the treatment $\mathrm{S}_{2}$ that was statistically similar with $S_{1}$ and $S_{3}$ nutrient level treatments with the value of 11.10 and $11.50 \%$ respectively (Table 2). Similar results were reported that improvement in grain yield, protein content as a result of $\mathrm{Fe}$ and $\mathrm{Zn}$ spraying by Yuan et al. (2012).

Starch

A significant variation of starch content was recorded due to different nutrient level treatments. The starch due to different nutrient level treatments ranged from 63.85 to $58.40 \mathrm{mg} \mathrm{g}^{-1}$. The highest value $\left(63.85 \mathrm{mg} \mathrm{g}^{-1}\right)$ of starch manifested with treatment $\mathrm{S}_{6} . \mathrm{S}_{2}$ produced the lowest value (58.40 $\mathrm{mg} \mathrm{g}^{-1}$ ) of starch content that was statistically similar with $\mathrm{S}_{1}$ nutrient level treatment with the value of $59.45 \mathrm{mg} \mathrm{g}^{-1}$ (Table 2). 


\section{Iron}

Iron content in maize hybrid grain was significantly varied by the use of agronomic biofortification through INM. It was shown that the Fe content ranged from 37.80 to $21.20 \mathrm{mg} \mathrm{kg}^{-1}$. The highest Fe content in grain $(37.80 \mathrm{mg}$ $\mathrm{kg}^{-1}$ ) was found in the $\mathrm{S}_{6}$ treatment. The lowest result $\left(21.20 \mathrm{mg} \mathrm{kg}^{-1}\right)$ was recorded in $\mathrm{S}_{2}$ treatment which was statistically significant with $\mathrm{S} 1$ treatment with the value of $22.75 \mathrm{mg} \mathrm{kg}^{-1}$ (Table 2). The increased result was due to increase soil $\mathrm{N}$ application significantly enhanced shoot and grain $\mathrm{Fe}$ concentrations both under field and greenhouse conditions (Cakmak et al., 2010; Kutman et al., 2010). Also, it was found that foliar application of Fe and $\mathrm{Zn}$ proved a better way to increase the nutrient contents in maize grain in comparison with soil application (Saleem et al., 2016).

\section{Zinc}

The $\mathrm{Zn}$ content in grain was significantly varied due to agronomic biofortification through INM. It was showed that the $\mathrm{Zn}$ content ranged from 31.88 to $16.95 \mathrm{mg} \mathrm{kg}^{-1}$. The highest $\mathrm{Zn}$ content $\left(31.88 \mathrm{mg} \mathrm{kg}^{-1}\right)$ was found in the $\mathrm{S}_{6}$ treatment. The lowest result $\left(16.95 \mathrm{mg} \mathrm{kg}^{-1}\right)$ was obtained in the $\mathrm{S}_{2}$ treatment (Table 2). Agronomic biofortification through $\mathrm{Zn}$ fertilization results in increased grain production as well as higher $\mathrm{Zn}$ concentration in grains at the same time thus reported by Prasad (2009) and also Chakraborti et al., (2009) reported a higher concentration of $\mathrm{Zn}$ in QPM inbreds compared to normal inbreds.

\section{Nutrient Uptake}

\section{Nitrogen}

The nitrogen uptake at harvest was significantly higher (243.54 $\mathrm{kg} \mathrm{ha}^{-1}$ ) with $\mathrm{S}_{6}$ nutrient level treatment and significantly superior to the rest of the treatments. In $\mathrm{S}_{6}$ nutrient level treatment was highest in $\mathrm{N}$ uptake which was statistically similar with $\mathrm{S}_{3}$ with the value of $243.54 \mathrm{~kg} \mathrm{ha}^{-1}$. Significant lower nitrogen uptake $\left(224.55 \mathrm{~kg} \mathrm{ha}^{-1}\right)$ was recorded with $\mathrm{S}_{2}$ treatment (Table 3). The increase in grain yield and stover yield could be related to an increase in uptake of N, P, and K by the crop. All these nutrients are important in many physiological processes controlling growth and development in plants. The combined application of nitrogen and organics increased the concentration of nutrient ions in the soil solution and their uptake by plants. Similar findings were recorded by Reddy and Reddy (1998).

Phosphorus

Phosphorus uptake was significantly varied by the agronomic biofortification through INM. It was shown that the $\mathrm{P}$ uptake ranged from 44.65 to $41.17 \mathrm{~kg} \mathrm{ha}^{-1}$. The highest value $\left(44.65 \mathrm{~kg} \mathrm{ha}^{-1}\right)$ was found in the $\mathrm{S}_{6}$ nutrient level treatment. The lowest result $\left(41.17 \mathrm{~kg} \mathrm{ha}^{-1}\right)$ was recorded in $S_{2}$ nutrient level which was statistically significant with $S_{5}$ treatment with the value of $42.45 \mathrm{~kg} \mathrm{ha}^{-}$ 1 (Table 3). Integrated nutrient supply is one of the most important factors that determine the growth of the crop. The growth and yield are determined by the presence of sufficient quantities of the available form of nutrients in the soil for plant uptake. A similar result was found by Babannavar et al. (1990).

Potassium

A significant variation in the parameter was noted due to differences in treatments. The potassium uptake due to different treatments ranged from 175.89 to $162.18 \mathrm{~kg} \mathrm{ha}^{-1}$. The highest value $\left(175.89 \mathrm{~kg} \mathrm{ha}^{-1}\right)$ of potassium uptake manifested with the nutrient level treatment $S_{6}$ which was statistically similar with $\mathrm{S}_{3}$ nutrient level treatment with the value of $174.26 \mathrm{~kg} \mathrm{ha}^{-1}$ (Table 3). $\mathrm{S}_{2}$ treatment produced the lowest value $\left(162.18 \mathrm{~kg} \mathrm{ha}^{-1}\right)$. Higher nutrient content in the produce and higher biomass production of maize might be the pertinent reason for the higher uptake of nutrients. These findings are in close agreement with the results reported by Singh et al. (2011).

Table 3. Nutrient uptake and soil properties of hybrid maize (Zea mays L.) as influenced by Agronomic biofortification through INM

\begin{tabular}{|c|c|c|c|c|c|c|c|}
\hline \multirow{3}{*}{ Treatments } & \multicolumn{3}{|c|}{ Nutrient uptake $\left(\mathrm{kg} \mathrm{ha}^{-1}\right)$} & \multicolumn{4}{|c|}{ Soil properties } \\
\hline & \multicolumn{3}{|c|}{ At harvest stage } & \multicolumn{4}{|c|}{ Post-harvest } \\
\hline & $\mathrm{N}$ & $\mathrm{P}$ & $\mathrm{K}$ & $\mathrm{OC}$ & MIN & AVAP & AVAK \\
\hline \multicolumn{8}{|c|}{ Hybrid $(\mathrm{H})$} \\
\hline$M_{1}-$ Non-biofortified & 237.99 & 43.63 & 171.90 & 0.410 & 229.00 & 12.30 & 539.43 \\
\hline $\mathrm{M}_{2}-$ biofortified & 233.22 & 42.76 & 168.43 & 0.409 & 226.23 & 12.06 & 537.33 \\
\hline \multicolumn{8}{|c|}{ Nutrient levels (N) } \\
\hline $\mathrm{S}_{1}$ & 237.92 & 43.62 & 171.83 & 0.410 & 228.25 & 12.25 & 541.35 \\
\hline $\mathrm{S}_{2}$ & 224.55 & 41.17 & 162.18 & 0.408 & 219.10 & 11.50 & 518.75 \\
\hline $\mathrm{S}_{3}$ & 241.25 & 44.24 & 174.26 & 0.415 & 239.25 & 13.14 & 558.90 \\
\hline $\mathrm{S}_{4}$ & 234.86 & 43.06 & 169.62 & 0.406 & 225.25 & 12.00 & 539.25 \\
\hline $\mathrm{S}_{5}$ & 231.53 & 42.45 & 167.21 & 0.406 & 218.25 & 11.35 & 516.85 \\
\hline $\mathrm{S}_{6}$ & 243.54 & 44.65 & 175.89 & 0.412 & 235.60 & 12.85 & 555.20 \\
\hline \multicolumn{8}{|l|}{ F test Prob. } \\
\hline $\mathrm{H}$ & $* *$ & $* *$ & $* *$ & N.S & $* *$ & $* *$ & $* *$ \\
\hline $\mathrm{N}$ & $* *$ & $* *$ & $* *$ & $* *$ & $* *$ & $* *$ & $* *$ \\
\hline $\mathrm{H} \times \mathrm{N}$ & $* *$ & $* *$ & $* *$ & $* *$ & $* *$ & $* *$ & $* *$ \\
\hline
\end{tabular}

OC: Organic Carbon (\%), MIN: Mineralizable N (kg ha $\left.{ }^{-1}\right)$, AVAP: Available P (kg ha $\left.{ }^{-1}\right)$, AVAK: Available K (kg ha-1), N: nitrogen, P: phosphorus, K: potassium, FYM: farm yard manure, RDF: recommended dose of fertilizer, **significantly different at 0.05 probability levels, N.S: not significant $\mathrm{S}_{1}: \mathrm{S}_{1}-100 \%$ RDF through NPK, $\mathrm{S}_{2}: \mathrm{S}_{2}-100 \%$ RDF through FYM, $\mathrm{S}_{3}: \mathrm{S}_{3}-50 \%$ RDF through NPK $+50 \%$ RDF through FYM, $\mathrm{S}_{4}: \mathrm{S}_{4}-\mathrm{S}_{1}+$ Iron and Zinc as foliar application @ $0.5 \%$ conc, $\mathrm{S}_{5}: \mathrm{S}_{5}-\mathrm{S}_{2}+$ Iron and Zinc as foliar application @ $0.5 \%$ conc, $\mathrm{S}_{6}: \mathrm{S}_{6}-\mathrm{S}_{3}+$ Iron and Zinc as foliar application @ $0.5 \%$ conc 
Table 4. Interaction effect of Hybrids and Nutrient levels on yield, net returns and benefit: cost ratio

\begin{tabular}{|c|c|c|c|c|}
\hline Hybrid & Nutrient level & Grain yield $\left(\mathrm{t} \mathrm{ha}^{-1}\right)$ & Net returns $\left(\times 10^{3} \mathrm{INR} / \mathrm{ha}\right)$ & Benefit:cost ratio \\
\hline \multirow{6}{*}{$M_{1}-$ Non-biofortified } & $\mathrm{S}_{1}$ & 8.55 & 81696.00 & 3.14 \\
\hline & $\mathrm{S}_{2}$ & 8.38 & 76303.60 & 2.86 \\
\hline & $\mathrm{S}_{3}$ & 8.61 & 80990.80 & 3.04 \\
\hline & $\mathrm{S}_{4}$ & 8.50 & 80407.20 & 3.08 \\
\hline & $\mathrm{S}_{5}$ & 8.44 & 76612.40 & 2.84 \\
\hline & $\mathrm{S}_{6}$ & 8.70 & 81705.00 & 3.04 \\
\hline \multirow{6}{*}{$\mathrm{M}_{2}-$ Biofortified } & $\mathrm{S}_{1}$ & 7.75 & 75838.13 & 2.99 \\
\hline & $\mathrm{S}_{2}$ & 7.41 & 69114.40 & 2.68 \\
\hline & $\mathrm{S}_{3}$ & 7.78 & 69408.20 & 2.75 \\
\hline & $\mathrm{S}_{4}$ & 7.70 & 68691.47 & 2.78 \\
\hline & $\mathrm{S}_{5}$ & 7.56 & 64231.00 & 2.54 \\
\hline & $\mathrm{S}_{6}$ & 7.85 & 69723.00 & 2.74 \\
\hline $\mathrm{SEm} \pm$ & & 17.76 & 1587.40 & 0.04 \\
\hline $\mathrm{CD}(\overline{\mathrm{P}}=0.05)$ & & 37.35 & 4345.77 & 0.11 \\
\hline
\end{tabular}

RDF: recommended dose of fertilizer, N: nitrogen, P: phosphorus, K: potassium, FYM: farm yard manure, **significantly different at 0.05 probability levels, $S_{1}: S_{1}-100 \%$ RDF through NPK, $S_{2}: S_{2}-100 \%$ RDF through FYM, $S_{3}: S_{3}-50 \%$ RDF through NPK + 50\% RDF through FYM, $S_{4}: S_{4}-S_{1}+$ Iron and Zinc as foliar application @ $0.5 \%$ conc, $\mathrm{S}_{5}: \mathrm{S}_{5}-\mathrm{S}_{2}+$ Iron and Zinc as foliar application @ $0.5 \%$ conc, $\mathrm{S}_{6}$ : $\mathrm{S}_{6}-\mathrm{S}_{3}+$ Iron and Zinc as foliar application@0.5\% conc

\section{Soil Available Nutrients}

\section{Soil Organic Carbon (SOC \%)}

SOC is a major constituent of organic matter, and $58 \%$ of estimated organic matter is evaluated through organic carbon. A highly significant increase in SOC was noticed due to treatment effects on the soil after harvest. The maximum increased SOC $(0.415 \%)$ at harvest was observed in treatment containing $\mathrm{S}_{3}(50 \%$ RDF through NPK $+50 \%$ RDF through FYM) which was statistically similar with $S_{6}$ and $S_{1}$, that resulted in superior growth during the crop growing period, whereas the lowest $(0.406 \%)$ among the nutrient level treatments was observed in $\mathrm{S}_{4}$ and $\mathrm{S}_{5}$ (Table $3)$. The SOC and total nitrogen are interrelated. It has been reported that the organic matter in soil increases with an increase in the level of applied N, which in turn causes an increase in total nitrogen content. The results corroborated with the findings of Kannan et al. (2013).

Soil Available Nitrogen ( $S A N, \mathrm{~kg} \mathrm{ha}^{-1}$ )

Organic manures integrated with inorganic fertilizers in maize have increased soil health as compared to the lone application of fertilizers. The highest significant difference was recorded $\left(239.25 \mathrm{~kg} \mathrm{ha}^{-1}\right)$ with the nutrient level treatment $S_{3}$, which contains a combination of organic and inorganic sources of nutrients which was found to be statistically similar with $\mathrm{S}_{6}$ nutrient level treatment with the value of $235.60 \mathrm{~kg} \mathrm{ha}^{-1}$ (Table 3). The above result is similar to Sharma et al. (2012) and Maidul et al. (2018) who reported that integration of organics and inorganics improves soil fertility status.

\section{Soil Available Phosphorus (SAP, $\mathrm{kg} \mathrm{ha}^{-1}$ )}

The available soil $\mathrm{P}$ performed vital functions including root development to fruit formation. The highly significant difference was recorded due to the effect of organic and inorganic fertilizers on SAP after harvest. Compared with the rest of the nutrient level treatments used in this trial $\mathrm{S}_{3}$ (50\% RDF through NPK + 50\% RDF through FYM) was found to be the highest SAP $\left(13.14 \mathrm{~kg} \mathrm{ha}^{-1}\right)$ whereas, $\mathrm{S}_{5}\left(\mathrm{~S}_{2}\right.$ $+\mathrm{Fe}$ and $\mathrm{Zn}$ foliar @ $0.5 \%$ conc.,) was recorded with lowest SAP (11.35 kg ha-1) which was found to be statistically similar with $\mathrm{S}_{2}$ (100\% RDF through NPK) (Table 3). The results are in similarity with the findings of Sharma et al.
(2012) and Maidul et al. (2018) that application of FYM along with RDF increases soil fertility status.

\section{Soil Available Potassium ( $\mathrm{kg} \mathrm{ha}^{-1}$ )}

The effect of organic and inorganic fertilizers has shown a significant difference in soil available potassium after harvest. Compared with the rest of the nutrient level treatments used in this trial $\mathrm{S}_{5}\left(\mathrm{~S}_{2}+\mathrm{Fe}\right.$ and $\mathrm{Zn}$ foliar @ $0.5 \%$ conc.,) was found to have the lowest soil available potassium $\left(516.85 \mathrm{~kg} \mathrm{ha}^{-1}\right)$ whereas, $\mathrm{S}_{3}(50 \% \mathrm{RDF}$ through NPK + 50\% RDF through FYM) was recorded with the highest soil available potassium (558.90 $\left.\mathrm{kg} \mathrm{ha}^{-1}\right)$ than any other treatments used which was found to be statistically the same with $\mathrm{S}_{6}(50 \%$ RDF through NPK $+50 \%$ RDF through FYM with Fe and Zn foliar @ 0.5\% conc.,) in their action towards the improvement of soil available potassium (Table 3). Similar results were recorded by Pawar (1996) in maize that increases in available $\mathrm{K}_{2} \mathrm{O}$ content in soil due to combined application of urban compost or FYM and inorganic fertilizers.

\section{Interaction Effect of Hybrids and Nutrient Levels}

The interaction effect of hybrids and nutrient levels was observed on yield, net returns, and benefit: cost ratio (Table 4) indicated that maximum grain yield $\left(8.70 \mathrm{t} \mathrm{ha}^{-1}\right)$, net returns (INR $81705 \mathrm{ha}^{-1}$ ) recorded with non-biofortified hybrid $\left(\mathrm{M}_{1}\right)$ with $\mathrm{S}_{6}$ nutrient level treatment and significantly superior over rest interactions. Similarly benefit: cost ratio was maximum (3.14) in non-biofortified hybrid $\left(\mathrm{M}_{1}\right)$ with $\mathrm{S}_{1}$ nutrient level treatment, which was closely followed by $S_{3}$ and $S_{6}$ with the value of 3.04. The lowest value of yield, net returns, and benefit: Cost ratios were recorded under the biofortified $\left(\mathrm{M}_{2}\right)$ hybrid with $\mathrm{S}_{2}$ nutrient level treatment. It indicates that every hybrid needs a different nutrient management strategy for the realization of the highest yield and profit.

\section{Conclusion}

The findings of the present investigation revealed that among different nutrient level treatments, $50 \%$ RDF through NPK + $50 \%$ RDF through FYM with Fe and Zn foliar application @0.5\% Conc., $\left(\mathrm{S}_{6}\right)$ registered the 
maximum highest growth attributes, crop phenology, yield and yield attributes, quality attributes, nutrient uptake, whereas higher net returns were observed in $100 \%$ RDF through NPK $\left(\mathrm{S}_{1}\right)$. Likewise organic carbon and soil available nutrients were higher in 50\% RDF through NPK $+50 \%$ RDF through FYM $\left(\mathrm{S}_{3}\right)$. Similarly interaction effect of non-biofortified maize hybrid $\left(\mathrm{M}_{1}\right)$ was superior to biofortified maize hybrid with $50 \%$ RDF through NPK + $50 \%$ RDF through FYM with Fe and $\mathrm{Zn}$ foliar application @ $0.5 \%$ Conc., $\left(\mathrm{S}_{6}\right)$ treatment in all the parameters except quality attributes.

\section{References}

AGRES software package. 2020. Tamil Nadu Agricultural University, Coimbatore, India.

Agyenium SB, J Zickermann, M Kornoohrens. 2006. Poultry manure effect on growth and yield of maize. West Africa J. Appl. Ecol., 9: 1-11.

Ahmad W, Jan MT, Ilyas M, Shah T, Moinullah KA, Ahmad A, Khan S. 2017. Phenology and yield components of maize as influenced by different forms of dairy manure with supplemental nitrogen management. International Journal of Agricultural and Environmental Research 3(1): 137146.

Ali M, Ali A, Tahir M, Yaseen M. 2012. Growth and Yield response of hybrid maize through integrated phosphorus management. Pakistan Journal of Life and social sciences 10:59-66.

Amanullah MM. 1997. Effect of intercropping fertilizer levels and organic manures on the growth and yield of cassava (Manihot escluenta crantz). PhD Dissertation, TNAU, Coimbatore.

Augustine R, Kalyanasundaram D. 2020. Agronomic biofortification through micronutrient management in maize. Journal of Applied and Natural Science, 12: 430-437.

ASTM. Annual Book of ASTM Standards 2001. In American Society for Testing and Materials, 100 Barr Harbor Drive: West Conshohocken, PA, USA.

Ayoola OT, EA Makinde. 2009. Maize growth, yield and soil nutrient changes with $\mathrm{N}$-enriched organic fertilizers. African Journal of food, agriculture, nutrition and development, 9(1): 580-592.

Babannvar VP, Pleshi CM, Balachandra N. 1990. Effect of organic matter on crop yield, physical and chemical properties of a Vertisols. Journal of the Indian Society of Soil Science, 38:426-429.

Bukesh MA, Ahmad R, Iqbal J, Maqbool MM, Ali A, Ishaque M, Hussainc S. 2012. Nutritional and physiological significance of potassium application in maize hybrid crop production. Pak. J. Nutr., 11(2): 187-202.

Cakmak I, Pfeiffer WH, McClafferty B. 2010. Biofortification of durum wheat with zinc and iron. Cereal Chem., 87(1): 10-20.

Chakraborti M, Prasanna BM, Hossain F, Singh AM, Guleria S.K. 2009. Genetic evaluation of kenel $\mathrm{Fe}$ and $\mathrm{Zn}$ concentrations and yield performance of selected maize (Zea mays L.) genotypes. Range Management and Agro-forestry, 30: 109-114.

Global food policy report 2016. International Food Policy Research Institute (IFPRI). Washington, DC.

Gomez KA, Gomez AA. 1984. Statistical procedure for agricultural research. II edn. John Wiley and Sons, New York, 680p.

Guleria SK, Chahota RK, Kumar P, Kumar A, Prasanna BM, Hossain F, Gupta HS. 2013. Analysis of genetic variability and genotype $\mathrm{x}$ year interactions on kernel zinc concentration in selected Indian and exotic maize (Zea mays L.) genotypes. Indian Journal of Agricultural Sciences, 83: 836-841.
Hythum M, Nasser Kh. 2012. Importance of Micronutrients and its Application Methods for Improving Maize (Zea mays L.) Yield Grown in Clayey Soil. American-Eurasian J. Agric. \& Environ. Sci., 12(7): 954-959

Ibrikci H, Ulger AC, Korkmaz K, Okdem A, Buyuk G, Amar B, Konuskan O, Karnez E, Ozgenturk G, Oguz H, Ryan J. 2009: Genotypic responses of corn to phosphorus fertilizer rates in calcareous soils. Commun. Soil Sci. Plant Anal. 40, 14181435.

Impa SM, Johnson-Beebout, SE. 2012. Mitigating zinc deficiency and achieving high grain $\mathrm{Zn}$ in rice through the integration of soil chemistry and plant physiology research. Plant Soil 361: 3-41.

Kannan RL, Dhivya M, Abinaya D, Krishna RL, Kumar SK. 2013. Effect of Integrated Nutrient Management on Soil Fertility and Productivity in Maize. Bull. Env. Pharmacol. Life Sci., 2(8): 61-67.

Kolawale E, Samson UR. 2009. Growth and Yield of Maize as Influenced by sowing date and Poultry Manure Application. Not. Bot. Hort. Agrobot. Cluj., 37(1): 199-203.

Korkmaz K, Akgün M, Özcan MM, Özkutlu F, Kara SM. 2021. Interaction effects of phosphorus (P) and zinc ( $\mathrm{Zn})$ on dry matter, concentration and uptake of $\mathrm{P}$ and $\mathrm{Zn}$ in chia. Journal of Plant Nutrition, 44(5), 755-764.

Kruczek A. 2005. Effect of row fertilization with different kinds of fertilizers on the maize yield. Acta Scientiarum Polonorum. Agricultura (Poland).

Kumar P, Halepyati AS, Pujari BT, Desai BK. 2007. Effect of integrated nutrient management on productivity, nutrient uptake and economics of maize (Zea mays L.) under rainfed condition. Karnataka Journal of Agricultural Sciences, 20(3): 462-65.

Kumari N, Singh AK., Pal SK, Thakur R. 2010. Effect of organic nutrient management on yield, nutrient uptake and nutrient balance sheet in scented rice (Oryza sativa). Indian Journal of Agronomy, 55(3):220-23.

Kutman UB, Yildiz B, Ozturk L, Cakmak I. 2010. Biofortification of durum wheat with zinc through soil and foliar applications of nitrogen. Cereal Chem., 87:1-9.

Jat, ML, Satyanarayana T, Majumdar K, Parihar CM, Jat SL, Tetarwal JP, Jat RK, Saharwat YS. 2013. Fertilizers best management practices for maize systems. Indian Journal of Fertilizers, 9(4): 80-94.

Maidul H, Tushar KR, Manirul Islam KM, Younus Ali SM, Noor Muhammad, Ataur R, Nitay CB. 2018. Growth and Yield of Hybrid Maize as Influenced by Fertilizer Management. Turkish Journal of Agriculture - Food Science and Technology, 6(12): 1727-1733.

Masuka B, Atlin GN, Olsen M, Magorokosho C, Labuschagne M, Crossa J, Banziger M, Pixley KV, Vivek BS, Von Biljion A. 2017. Grains in genetic improvement in Eastern and Southern Africa: I. CIMMYT hybrid breeding pipeline. Crop Sci., 57:168-179.

Monika G, Natasha S, Saloni S, Payal K, Aman K, Venkatesh C, Priya A. 2018. Biofortified Crops Generated by Breeding, Agronomy, and Transgenic Approaches Are Improving Lives of Millions of People around the World. Frontiers in Nutrition, 5: 12.

Moehn S, Pencharz PB, Ball RO. 2012. Lessons learned regarding symptoms of tryptophan deficiency and excess from animal requirement studies. Journal of Nutrition, 142:2231.

Muhammad S, Gulam J, Ejaz R, Muhammad EA, Arshad NC. 2012. Impact of Integrated Nutrient Management on Yield and Nutrient Uptake by Maize under Rain-Fed Conditions. Pakistan Journal of Nutrition, 11: 27-33.

Nikhil K, Salakinkop SR. 2018. Agronomic Biofortification of Maize with Zinc and Iron Micronutrients. Modern Concepts \& Development in Agronomy, 1(5): 2-5. 
Okoroafor I, Okelola E, Edeh O, Nemehute V, Onu C, Nwaneri T, Chinaka G. 2013. Effect of organic manure on the growth and yield performance of maize in Ishiagu, Ebonyi State, Nigeria. IOSR J. Agric. Vet. Sci., 5: 28-31.

Pawar RB. 1996. Dynamics of earthworm soil plant relationship in semiarid tropics. PhD Dissertation, University of Agricultural Sciences, Dharwad.

Pfeiffer WH, McClafferty B. 2007. Harvest Plus: breeding crops for better nutrition. Crop Science, 47: S88-S105.

Prasad R. 2009. Ferti-fortification of grains - an easy option to alleviate malnutrition of some micronutrients in human beings. Indian J. Fert., 5(12): 129-133.

Reddy BG, Reddy MSN. 1998. Effect of organic manures and nitrogen levels on soil available nutrient status in maizesoybean cropping system. Journal of the Indian Society of Soil Science, 46(3): 474-476.

Rengel Z, GD Batten, DE Crowley. 1999. Agronomic approaches for improving the micronutrient density in edible portions of field crops. Field Crop Research, 60: 27-40.

Sadiq N, Abdur R, Muhammad I, Muhammad AB, Muhammad Faraz A, Fiaz A. 2018. Organic manures: an efficient move towards maize grain. International Journal of Recycling of Organic Waste in Agriculture, 7: 189-197.

Saleem I, Javid S, Bibi F, Ehsan S, Niaz A, Ahmad ZA. 2016. Biofortification of maize grain with zinc and iron by using fertilizing approach. Journal of Agriculture and Ecology Research International, 7(4):1-6.

Saleh GB, Abdullah D, Amar AR. 2002. Performance, heterosis and heritability in selected tropical maize single double and three way cross hybrids. Journal of Agriculture Science, 138(1):21-28.

Samsami S. 2016. Effect of vermicompost on yield and yield components of two corn cultivars. International Journal of Environment, Agriculture and Biotechnology, 1(3): 445-447.
Sharma RC, Banik P. 2012. Effect of integrated nutrient management on baby corn-rice cropping system; economic yield, system productivity, nutrient-use efficiency and soil nutrient balance. Ind. J. Agric. Sci., 82(3):220-224.

Singh GP, Singh PL, Panwar AS. 2011. Response of groundnut (Arachis hypogaea L.) to biofertilizer, organic and inorganic sources of nutrient in north east India. Legume Research, 34(3): 196-201.

Steur HD, Blansquaert D, Strobbe S, Lambert W, Gellynck X, Straeten DVD. 2015. Status and market potential of transgenic biofortified crops. Nature Biotechnology, 33: 2529.

Tanumihardjo SA, Anderson C, Kaufer-Horwitz M, Bode L, Emenaker NJ, Haqq AM, Satia JA, Silver H, Stadler DD. 2007. Poverty, Obesity and malnutrition: an international perspective recognizing the paradox. Journal of the American Dietetic Association, 107: 1966-1972.

Undie UL, Uwah DF, Attoe EE. 2012. Effect of intercropping and crop arrangement of yield and productivity of late season maize/soybean mixtures in the humid environment of south southern Nigeria. J. Agric. Sci., 4:37-50.

Uwah DF, Udoh AU, Iwo GA. 2011. Effect of organic and mineral fertilizers on growth and yield of cocoyam (Colocasia Esculenta L..) Schott). Int J Agr Sci., 3.1:33-38.

Yuan L, Wu L, Yang C, Lv Q. 2012. Effects of iron and zinc foliar application on rice plants and their grain accumulation and grain nutritional quality. Journal of Science of Food and Agriculture, 93:254-261.

Zeidan MS, Mohamed MF, Hamouda HA. 2010. Effect of foliar fertilization of $\mathrm{Fe}, \mathrm{Mn}$ and $\mathrm{Zn}$ on wheat yield and quality in low sandy soils fertility. World Journal of Agricultural Sciences, 6(6): 696-699. 